\title{
CURVATURE ANALYSIS FOR COMPOSITE WITH ORTHOGONAL, ASYMMETRICAL MULTI-LAYER STRUCTURE
}

\author{
Jānis Šliseris ${ }^{1}$, Kārlis Rocēns ${ }^{2}$ \\ ${ }^{1,2}$ Riga Technical University, 1 Kalku Street, LV-1658 Riga, Latvia

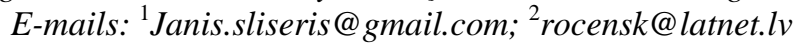

Received 28 Sept. 2009; accepted 19 Jan. 2010

\begin{abstract}
An option for reducing material consumption in bent construction is flat plate replacement with a curved or saddle shaped plate (shell). This option applies to plywood sheet, provided that the curved or saddle shaped plates are made in widely used multilevel plywood presses with parallel shelves using layers with an appropriate physical properties, geometric dimensions and orientation, creating a structurally asymmetrical sheet, relative to mid-surface. Improved currently used method for calculation of curvature with taking into account curvature interaction effect and elastic characteristic change in moisture changing process. Compared results obtained by improved method and finite element method. Using improved method calculated values of curvature for a sheet with different geometrical properties and moisture conditions.
\end{abstract}

Keywords: displacements; curvature interaction; wood composite; moisture influence on elastic properties; saddle-shaped surface.

\section{Introduction}

A composite with multilayer asymmetric structure acquires curvature during conditioning in varying moisture and temperature. The asymmetric structure is obtained by orientating layers in different directions. There are many factors that affect curvature. The most important are the geometrical properties of a sheet- its thickness and orientation of layers, temperature and moisture variation. Layers are made from an orthotropic material with various thermal or moisture expansion coefficients in different directions. In the case of a wood composite, the moisture changing process affects curvature more then the temperature changing process, therefore the moisture changing process is analyzed in details.

There are other factors that affect the curvature. For sheets with relatively large curvature it is important to take into account geometrical nonlinearity. It means that the curvature in one direction depends on the curvature in an orthogonal direction. This effect is called the curvature interaction. The interaction decreases the values of curvature.

The variation of temperature and/or moisture changes the elastic properties of a material.

\section{Theoretical background}

The curvature calculation could be done by using an algorithm, described in Ambarcumian (Амбарцумян 1961), Decolon (2002), Reissner and Stavsky (1961), Rocens and Steiners (1976), Skudra (2002). This analytical method for the curvature calculation is based on Kirchoff-Love's theory of a thin plate. The calculation starts with the general Hooke's law

$$
\left[\sigma_{i}\right]=\left[C_{i j}\right] \cdot\left[\varepsilon_{i}\right],
$$

where $\mathrm{i}, \mathrm{j}=1 . .6$; $\left[\sigma_{i}\right]-$ a stress matrix; $\left[C_{i j}\right]-$ a stiffness matrix; $\left[\varepsilon_{i}\right]-$ a strain matrix.

The general Hooke's Law can be modified using Kirchoff's hypothesis Reddy (1997), Vinson and Sierakovski (1986), Whitney (1987) of a thin plate and technical expressions. Thereby eq. (1) reduces to

$$
\left[\begin{array}{l}
\sigma_{1} \\
\sigma_{2} \\
\tau_{12}
\end{array}\right]=\left[\begin{array}{ccc}
\frac{E_{1}}{1-v_{12} v_{21}} & \frac{v_{21} E_{1}}{1-v_{12} v_{21}} & 0 \\
\frac{v_{12} E_{2}}{1-v_{12} v_{21}} & \frac{E_{2}}{1-v_{12} v_{21}} & 0 \\
0 & 0 & 0
\end{array}\right] \cdot\left[\begin{array}{l}
\varepsilon_{1} \\
\varepsilon_{2} \\
\gamma_{12}
\end{array}\right],
$$

where $E_{1}, E_{2}$ - modulus of elasticity in direction 1 , respectively 2; $v_{12} ; v_{21}$ - Poisson ratio; $G_{12}$ - shear modulus.

Eq. (2) uses a local coordinate system 1-2-Z. In case of a composite sheet, stress and strain have to be calculated in a global coordinate system X-Y-Z. The stress matrix is calculated in another coordinate system using the transformed stiffness matrix

$$
\left[\begin{array}{c}
\sigma_{X} \\
\sigma_{Y} \\
\tau_{X Y}
\end{array}\right]=\left[\overline{Q_{i j}}\right] \cdot\left[\begin{array}{c}
\varepsilon_{X} \\
\varepsilon_{Y} \\
\gamma_{X Y}
\end{array}\right],
$$

where $i, j=1,2,3 ;\left[\overline{Q_{i j}}\right]$ - the transformed stiffness matrix. 
The geometrical relationship between the deflection of mid-surface, $w_{0}$, and the horizontal displacement of the mid surface, $u_{0}, v_{0}$, as well as the strains, $\varepsilon_{i}$, is

$$
\left\{\begin{array}{l}
\varepsilon_{X}=\frac{\partial u_{0}}{\partial x}-z \frac{\partial^{2} w_{0}}{\partial x^{2}}, \\
\varepsilon_{Y}=\frac{\partial v_{0}}{\partial y}-z \frac{\partial^{2} w_{0}}{\partial y^{2}} \\
\varepsilon_{X Y}=\frac{\partial u_{0}}{\partial y}+\frac{\partial v_{0}}{\partial x}-2 z \frac{\partial^{2} w_{0}}{\partial y \partial x}
\end{array}\right.
$$

where $w_{0}$ - the deflection of plate mid surface, a function of $\mathrm{x}$ and $\mathrm{y} ; u_{0}, v_{0}$ - the horizontal displacement of plate mid surface, a function of $\mathrm{x}$ and $\mathrm{y} ; \mathrm{z}$ measures the position on $\mathrm{Z}$ axis which is orthogonal to plate surface (see Fig. 1).

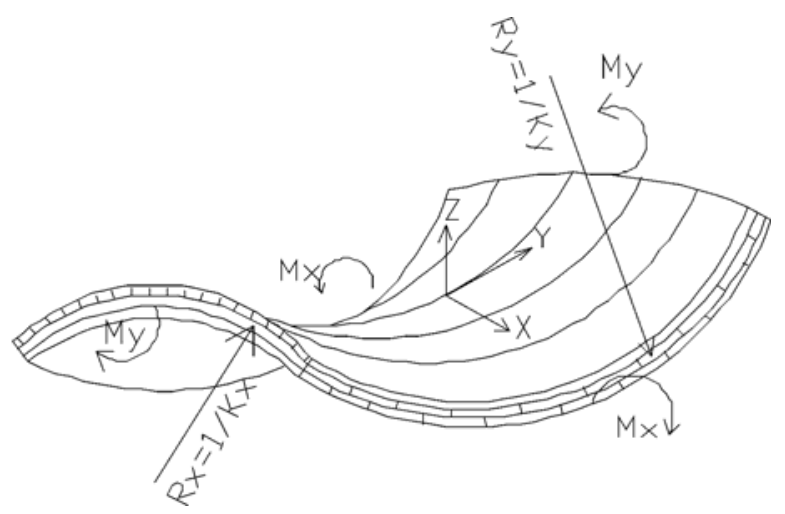

Fig. 1. The geometric interpretation of curvature

From eqs. (4) one can separate the curvature matrix

$$
\left[\begin{array}{c}
k_{X}^{0} \\
k_{Y}^{0} \\
k_{X Y}^{0}
\end{array}\right]=-\left[\begin{array}{c}
\frac{\partial^{2} w_{0}}{\partial x^{2}} \\
\frac{\partial^{2} w_{0}}{\partial y^{2}} \\
\frac{\partial^{2} w_{0}}{\partial y \partial x}
\end{array}\right],
$$

where $k_{X}^{0}, k_{Y}^{0}$ - the curvature of mid-surface relative to axes x, resp. y; $k_{X Y}^{0}-$ the torsion angle of mid-surface.

The geometrical eqs. $(4,5)$ and the physical eqs. (3) can be joined:

$$
\left[\sigma_{u}\right]=\left[\bar{Q}_{i j}\right] \cdot\left[\left[\varepsilon_{u}^{0}\right]+z\left[k_{u}^{0}\right]\right],
$$

where $u=x, y$, or $x y$; $\left[\varepsilon_{u}^{0}\right]$ - mid-surface strain matrix.

In order to simplify the deformation model it is helpful to transform the stress matrix into an equivalent system that yields matrices of moment and force per unit length.

The force matrix is obtained by summing the stress matrix coefficients across the $\mathrm{z}$ dimension of a sheet

$$
\left[\begin{array}{c}
N_{X}^{0} \\
N_{Y}^{0} \\
N_{X Y}^{0}
\end{array}\right]=\int_{\frac{-h}{2}}^{\frac{h}{2}}\left[\begin{array}{c}
\sigma_{X} \\
\sigma_{Y} \\
\tau_{X Y}
\end{array}\right] d z=\sum_{k=1}^{N} \int_{z_{k-1}}^{z_{k}}\left[\begin{array}{c}
\sigma_{X} \\
\sigma_{Y} \\
\tau_{X Y}
\end{array}\right]_{k} d z
$$

where $N_{X}^{0} ; N_{Y}^{0}$ - axial force in direction x and y, acting on mid-surface; $N_{X Y}^{0}$ - torsion force in direction xy; hthickness of the sheet; $N$ - number of layers in the sheet; $z_{k}, z_{k-1}-$ final, resp. initial coordinate of layer $k$.

The moment matrix is a sum over the layers of the integral of the product of the stress matrix and $z$ coordinate of the sheet

$$
\left[\begin{array}{c}
M_{X}^{0} \\
M_{Y}^{0} \\
M_{X Y}^{0}
\end{array}\right]=\int_{\frac{-h}{2}}^{\frac{h}{2}}\left[\begin{array}{c}
\sigma_{X} \\
\sigma_{Y} \\
\tau_{X Y}
\end{array}\right] z d z=\sum_{k=1_{Z_{k-1}}^{N}}^{z_{k}}\left[\begin{array}{c}
\sigma_{X} \\
\sigma_{Y} \\
\tau_{X Y}
\end{array}\right]_{k} z d z,
$$

where $M_{X}^{0}, M_{Y}^{0}-\mathrm{x}$, resp. y moment of the mid-surface; $M_{X Y}^{0}$ - the torsion moment acting in the xy plane on mid-surface.

By integrating eqs. (7) and (8) one gets two expressions in terms of matrices $A, B, D$ :

$$
\left[\begin{array}{c}
N_{X}^{0} \\
N_{Y}^{0} \\
N_{X Y}^{0}
\end{array}\right]=\left[A_{i j}\right] \cdot\left[\begin{array}{c}
\varepsilon_{x}^{0} \\
\varepsilon_{X}^{0} \\
\gamma_{x y}^{0}
\end{array}\right]+\left[B_{i j}\right] \cdot\left[\begin{array}{c}
k_{X}^{0} \\
k_{Y}^{0} \\
k_{X Y}^{0}
\end{array}\right]
$$

and

$$
\left[\begin{array}{c}
M_{X}^{0} \\
M_{Y}^{0} \\
M_{X Y}^{0}
\end{array}\right]=\left[B_{i j}\right] \cdot\left[\begin{array}{c}
\varepsilon_{X}^{0} \\
\varepsilon_{X}^{0} \\
\gamma_{x y}^{0}
\end{array}\right]+\left[D_{i j}\right] \cdot\left[\begin{array}{c}
k_{X}^{0} \\
k_{Y}^{0} \\
k_{X Y}^{0}
\end{array}\right],
$$

where $i, j=1,2,3$;

The coefficients of matrices $A, B, D$ are calculated using the following equations

$$
\begin{aligned}
A_{i j} & =\sum_{k=1}^{N}\left(\overline{Q_{i j}}\right)_{k}\left(z_{k}-z_{k-1}\right), \\
B_{i j} & =\frac{1}{2} \sum_{k=1}^{N}\left(\overline{Q_{i j}}\right)_{k}\left(z_{k}^{2}-z_{k-1}^{2}\right), \\
D_{i j} & =\frac{1}{3} \sum_{k=1}^{N}\left(\overline{Q_{i j}}\right)_{k}\left(z_{k}^{3}-z_{k-1}{ }^{3}\right),
\end{aligned}
$$

Nature subjects sheets to many physical variables, including moisture. The force and the moment arising from varying degrees of moisture are calculated using the equations (Brauns and Rocens 1994, 1997, 2004)

$$
\begin{aligned}
& {\left[N_{u}^{0}\right]=\sum_{k=1}^{N}\left[\overline{Q_{i j}}\right]_{k}\left[\beta_{u}\right] \Delta W\left(z_{k}-z_{k-1}\right),} \\
& {\left[M_{u}^{0}\right]=\frac{1}{2} \sum_{k=1}^{N}\left[\overline{Q_{i j}}\right]_{k}\left[\beta_{u}\right] \Delta W\left(z_{k}^{2}-z_{k-1}^{2}\right),}
\end{aligned}
$$


where $\left[\beta_{u}\right]$ - the matrix coefficients of the moisture expansion of the material; $\Delta W$-the total moisture increment or decrement during a treatment process.

The combining eqs. (9), (10) and (12) yields a matrix expression that gives the deformation and curvature of the sheet:

$$
\left[\begin{array}{c}
{\left[\varepsilon_{u}^{0}\right]} \\
{\left[k_{u}^{0}\right]}
\end{array}\right]=\left[\begin{array}{cc}
{\left[A_{i j}\right]} & {\left[B_{i j}\right]} \\
{\left[B_{i j}\right]} & {\left[D_{i j}\right]}
\end{array}\right]^{-1}\left[\begin{array}{c}
{\left[N_{u}^{0}\right]} \\
{\left[M_{u}^{0}\right]}
\end{array}\right] .
$$

\section{Improved algorithm}

The most important failures of the currently used analytical method are:

- It ignores the change in the elastic properties of the material during moisture variation (also called "physical nonlinearity").

- It ignores the curvature interaction (also called "geometrical nonlinearity") Karkauskas (2007), Grigorenko and Yaremchenko (2009).

The model presented in this paper consists of an algorithm that is based on a single loop with $n$ iterations. That single loop divides the total moisture increment/decrement $-\Delta W$ into $n$ smaller steps $d W$ of the moisture. For each step one calculates new elastic properties of a material that result from the variation of moisture. Eq. (13) is replaced with

$$
\left[\begin{array}{l}
{\left[\varepsilon_{u}^{0}(w)\right]} \\
{\left[k_{u}^{0}(w)\right]}
\end{array}\right]_{l}=\left[\begin{array}{ll}
{\left[A_{i j}(w)\right]} & {\left[B_{i j}(w)\right]} \\
{\left[B_{i j}(w)\right]} & {\left[D_{i j}(w)\right]}
\end{array}\right]_{l}^{-1}\left[\begin{array}{l}
{\left[N_{u}^{0}(w)\right]} \\
{\left[M_{u}^{0}(w)\right]}
\end{array}\right]_{l},
$$

where $u=x, y, x y ; w-$ the average moisture of the sheet; $l$ - current step number.

For step number $l$ one calculates the deformation and curvature matrix as a function of a constant moisture increment/decrement - $d W$. The sum of the deformations and the torsion yields the deformation and torsion matrix

$$
\left[\begin{array}{l}
{\left[\varepsilon_{u}^{0}(w)\right]} \\
k_{X Y}^{0}(w)
\end{array}\right]=\sum_{l=1}^{n}\left[\begin{array}{c}
{\left[\varepsilon_{u}^{0}(w)\right]} \\
k_{X Y}^{0}(w)
\end{array}\right]_{l}
$$

In the each step the values of curvatures $k_{X}^{0}(w)_{l}$ and $k_{Y}^{0}(w)_{l}$ are corrected via multiplication by $\frac{I_{0, y}}{I_{l, y^{*}}}$ as shown in eq. (16). The total curvature matrix is the sum of the corrected curvature values:

$$
\left[\begin{array}{c}
\kappa_{X}^{0}(w) \\
\kappa_{Y}^{0}(w)
\end{array}\right]=\sum_{l=1}^{n}\left[\begin{array}{l}
k_{X}^{0}(w)_{l} \cdot \frac{I_{0, y}}{I_{l, y^{*}}} \\
k_{Y}^{0}(w)_{l} \cdot \frac{I_{0, x}}{I_{l, x^{*}}}
\end{array}\right]
$$

where $n$ - the total number of steps; $\kappa_{X}^{0}(w), \kappa_{Y}^{0}(w)$ corrected value of curvature $I_{0, x}, I_{0, y}$ - the moments of inertia for a flat plate which are calculated from eq. (17); $I_{l, x^{*}}, I_{l, y^{*}}-$ the moments of inertia for the curved plate after step $l$ - calculated from eq. (18); $x^{*}, y^{*}$ - central axis for curved plate after $l$ step.

$$
I_{0 u}=\frac{a_{u} \cdot h^{3}}{12}
$$

where $u=x, y ; a_{u}$ - length of sheet along direction $u$;

$$
\begin{aligned}
& I_{l, v}=\frac{a^{3}}{8} h \\
& \left(\frac{4 R_{u}{ }^{2}}{a}+\frac{\sin \left(\frac{2 R_{u}}{a}\right) \cos \left(\frac{2 R_{u}}{a}\right)}{\frac{8 R_{u}{ }^{3}}{a^{3}}}-\frac{2 \sin ^{2}\left(\frac{2 R_{u}}{a}\right)}{\frac{16 R_{u}{ }^{4}}{a^{4}}}\right)+\frac{a \cdot h^{3}}{12},
\end{aligned}
$$

where $R_{u}$ - radius of curvature in direction $u$, geometrical interpretation, shown in Fig. $1 ; v=x^{*}, y^{*}$.

In this algorithm a very important factor is the length of a sheet along direction $u$. The algorithm used in references Rocens (1983), Christensen (1991), Jones (1975) didn't take into account this geometrical factor.

Analytical experiments were carried out with the improved algorithm, using the computer program Matlab R2008a.

\section{Comparison of results}

The algorithm was applied to square-shaped $\left(I_{0, X}=I_{0, Y}\right)$ four-layered plywood sheets made from birch. The moment of inertia $I_{0, X}$ was varied during the experiments. The elastic properties of birch thee for two different values of wood moisture (6\% and $10 \%)$ is shown in Table 1, according to Beliankin (Белянкин 1957), Perelygin, Ugolev (Перелыгин, Уголев 1971), Ugolev (Уголев 1971). The elastic properties for different values of moisture are obtained using linear interpolation or extrapolation.

Table 1

\begin{tabular}{c|c|c|c|c|c}
\hline $\mathrm{W}, \%$ & $\mathrm{E}_{1}, \mathrm{Mpa}$ & $\mathrm{E}_{2}, \mathrm{Mpa}$ & $\begin{array}{c}\mathrm{G}_{12}, \\
\mathrm{Mpa}\end{array}$ & $v_{12}$ & $v_{21}$ \\
\hline 6 & 17600 & 650 & 1070 & 0.04 & 0.45 \\
\hline 10 & 16800 & 550 & 950 & 0.04 & 0.45 \\
\hline
\end{tabular}

* where index 1 - direction of wood grains, 2 - tangential direction of wood grains.

The grains of the first two layers ( $54.5 \%$ by volume of the sheet) are oriented in direction $Y$, the other two layers - in direction $X$. In all cases the area of a cross section (parallel to the $\mathrm{x}$ or $\mathrm{y}$ axes) of the sheet is $275 \mathrm{~cm}^{2}$. Analytical experiments were made by changing 
$I_{0, u}$ and the final wood moisture $-\mathrm{W}_{\text {fin }}$. The total moisture increment was kept constant at $4 \%$. To vary the moment of inertia of the initial flat plate, the ratio of the length of a sheet, a, to its thickness, $h$, was changed from 60 to 600 . The moment of inertia of a sheet increases as its thickness is increased and the length of its edge is decreased (see eq. (17)). The algorithm was applied to sheets with 30 different moments of inertia. The lowest moment of inertia $\left(I_{0, u}\right)$ was $10.6 \mathrm{~cm}^{4}\left(\frac{a}{h}=600\right.$; $a=406 \mathrm{~cm} ; \quad h=0.68 \mathrm{~cm})$ and highest $-104.5 \mathrm{~cm}^{4}$ $\left(\frac{a}{h}=60 ; a=128 \mathrm{~cm} ; h=2.14 \mathrm{~cm}\right)$.

To each of the thirty sheets fifteen different moisture regimes were applied, resulting 450 different experiments. Final wood moisture $W_{\text {fin }}$ was varied from $10 \%$ to $25 \%$, and the beginning wood moisture, $W_{\text {beg, }}$ was $4 \%$ below $W_{\text {fin }}$. $W_{\text {beg }}$ is the moisture level at which the sheet starts to curve. One hundred steps $(n=100)$ were used to calculate the curvature in each experiment. The results are shown in Figs. 2 and 3.

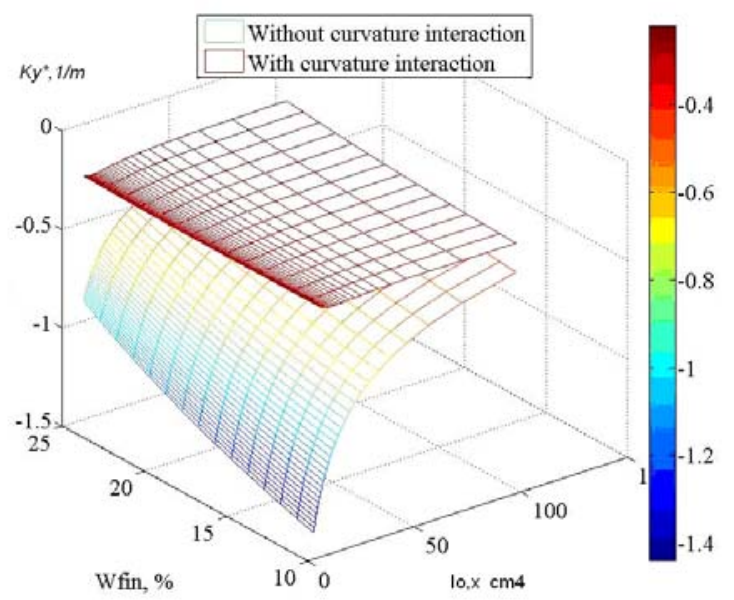

Fig. 2. The dominant (y axis) curvature dependence on the $I_{0, X}$ and $W_{\text {fin }}$ * Value of corrected curvature $-\kappa_{Y}^{0}$ and value of curvature without correction $-k_{Y}^{0}$

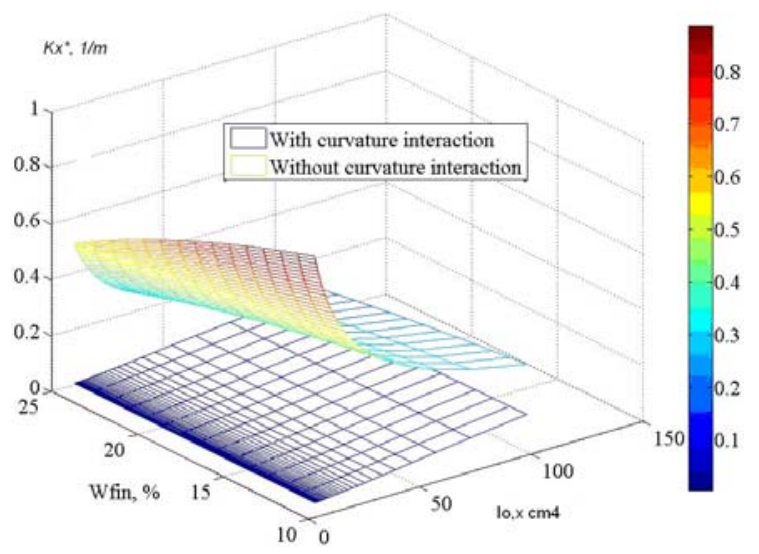

Fig. 3. The secondary ( $x$ axis) curvature dependence on the $I_{0, X}$ and $W_{f i n}$ * Value of corrected curvature- $\kappa_{X}^{0}$ and value of curvature without correction- $k_{X}^{0}$
A further four experiments were made using the finite element method Michnevič (2006) (computer program ANSYS v.10). The sheets used in these experiments differed from the previous sheets as follows: The first three layers were $1.5 \mathrm{~mm}$ thick; fourth layer $-1 \mathrm{~mm}$. The fibers of the first two layers were oriented along the $\mathrm{X}$ direction, fibers of the third and fourth - along the $\mathrm{Y}$ direction.

Each layer was divided into finite elements, Solid 45, taken from ANSYS v.10. The layers were modeled as an elastic orthotropic material. Its elastic properties were defined for two moisture levels - 10\% and 6\%. A linear function was used to approximate the elastic properties. The analysis of curvature was made with and without the large deformation effect (LDE, see ANSYS v.10) and for sheets with two different length of edge $a$ $50 \mathrm{~mm}$ and $200 \mathrm{~mm}$. The results are shown into Table 2 .

Table 2

\begin{tabular}{c|c|c|c|c}
\hline \multirow{2}{*}{$\mathrm{a}, \mathrm{mm}$} & \multicolumn{4}{|c}{ Ansys v.10 } \\
\cline { 2 - 5 } & \multicolumn{2}{|c}{ Without using LDE } & \multicolumn{2}{c}{ Using LDE } \\
\hline & $\kappa_{X}^{0}, 1 / \mathrm{m}$ & $\kappa_{Y}^{0}, 1 / \mathrm{m}$ & $\kappa_{X}^{0}, 1 / \mathrm{m}$ & $\kappa_{Y}^{0}, 1 / \mathrm{m}$ \\
\hline 50 & 1.1563 & -1.9379 & 1.0717 & -1.8828 \\
\hline 200 & 1.1780 & -1.4316 & 0.1601 & -1.2255 \\
\hline
\end{tabular}

\section{Numerical experiment}

There are many factors that affect the value of curvature. The most important are total thickness - h of sheet (see Fig. 4), ratio of length and width of sheet - b/a, value of moisture increment/decrement (difference between wood moisture content in manufacturing $\left(\mathrm{W}_{\text {beg }}\right)$ process and wood moisture content in exploitation $\left.\left(\mathrm{W}_{\text {fin }}\right)-\mathrm{dW}\right)$ and area of the sheet $-\mathrm{F}$ and ratio of thickness of longitudinal layers and shear layers $-\mathrm{h}_{1} / \mathrm{h}_{2}$

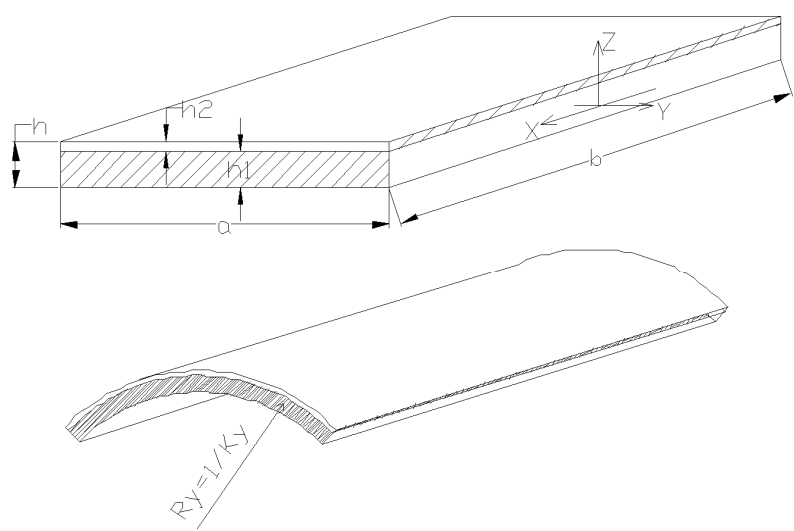

Fig. 4. Geometrical characteristics of sheet

By making a numerical experiments was studied the influence of mentioned factors on value of curvature. It was done by calculating the difference of value of curvature when one of mentioned factors is increased by $5 \%$. This experiment showed that the most significant factors that affect dominant curvature are- total thickness of sheet, ratio of length and width of sheet and value of 
moisture increment/decrement and ratio of thickness of longitudinal layers and shear layers. If the ratio of thickness of longitudinal and shear layers are more than 4 than ratio of length and width of sheet doesn't affect value of dominant curvature significantly (Fig. 6). The studies of relationship of the dominant curvature and ratio of thickness of longitudinal and shear layers and thickness of sheet is shown in Fig. 5. It shows that the maximal value of dominant curvature for any thickness of sheet is obtained when ratio of thickness of longitudinal and shear layers are form 5 to 5.5 (Figs. 5, 6).

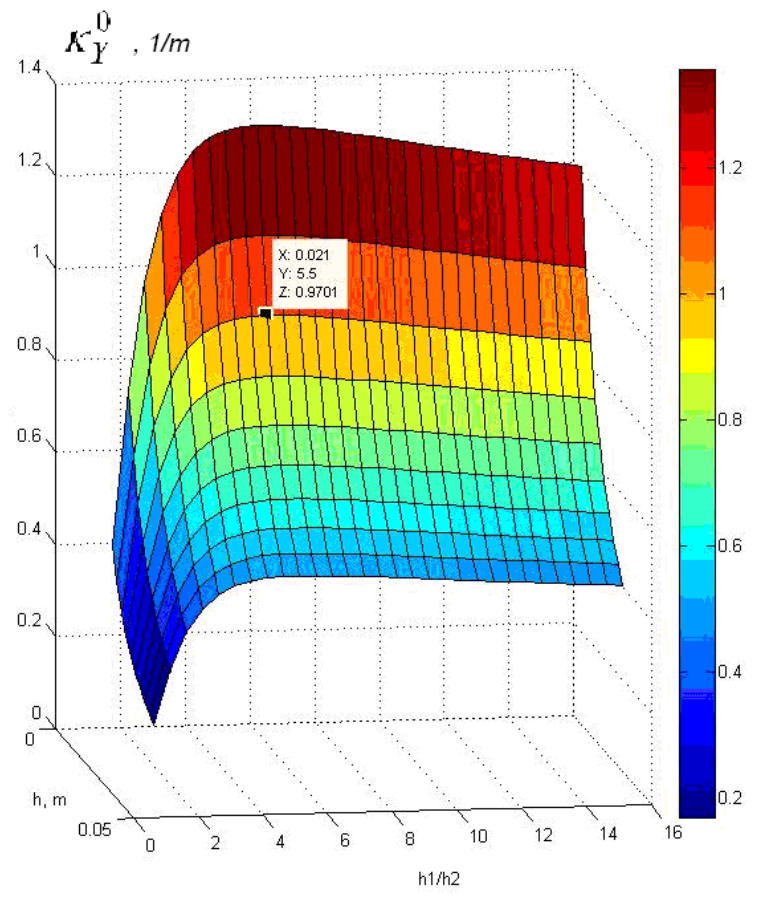

Fig. 5. $\mathrm{b} / \mathrm{a}=3, \mathrm{dW}=4 \%$. The dominant curvature dependence of thickness of sheet and ratio of thickness of longitudinal and shear layers

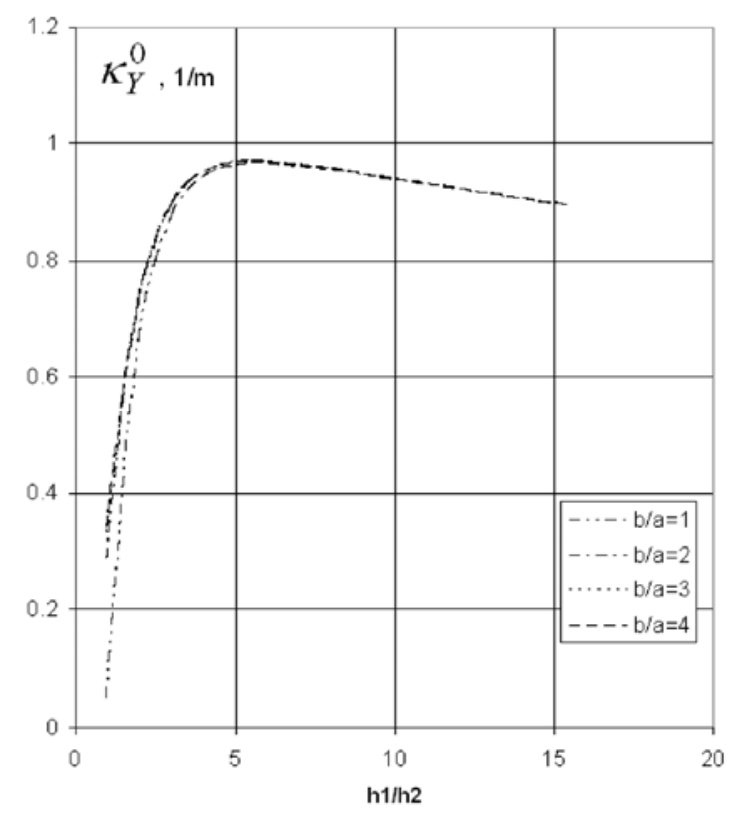

Fig. 6. The dominant curvature dependence of ratio of longitudinal and shear layers, if $\mathrm{h}=21 \mathrm{~mm}$ (from Fig. 5)
The obtained results were verified by finite element method in the most typical cases and difference is not more than $10 \%$.

To study the functional relationship of the most significant factors and value of the dominant curvature of sheet was done a numerical experiment. During the experiment was kept constant value of wood exploitation moisture $\mathrm{W}_{\text {fin }}=12 \%, \mathrm{~F}=12 \mathrm{~m}^{2}, \mathrm{~h}_{1} / \mathrm{h}_{2}=5, \mathrm{~b} / \mathrm{a}=3$ and orientation of layers of sheet. Curvature analysis was done by using improved algorithm. Structure of the sheet was following - $83 \%$ of wood grains are orientated in longitudinal direction (direction $X$, see Fig. 4) of the sheet and others orthogonally. Numerical experiment shows that sheet with such a structure obtains the dominant curvature $\left(\kappa_{Y}^{0}\right)$ that is more than 1000 times bigger than other $\left(\kappa_{X}^{0}\right)$ therefore other curvature might be ignored.

The value of curvature was calculated 9 times because variable factors are three and each of them take thee different values. Values of thickness of sheet $-\mathrm{h}$ and appropriate structure of sheet are shown in Fig. 4. Shear layers are orientated in direction $\mathrm{Y}$ others in direction $\mathrm{X}$ (longitudinal direction).

The total thickness of sheet takes 3 different values$18 \mathrm{~mm}, 27 \mathrm{~mm}$ and $36 \mathrm{~mm}$. Thickness of each layer is $1.5 \mathrm{~mm}$.

The value of moisture increment during the experiment takes values - 2\%, 4\%, 6\%. Appropriate values of moisture content of wood during the manufacturing process are $10 \%, 8 \%$ and $6 \%$.

During the experiment first variable factor $-\mathrm{h}$ was labeled as $\mathrm{X}_{1}$ and second variable - $\mathrm{dW}$ was labeled as $\mathrm{X}_{2}$. " 3 ") (two variables, each of them takes 3 different values) experiment plan was used to study functional relationship between the dominant curvature and thickness of sheet and moisture content of sheet during the manufacturing process.

The obtained results were approximated using second order polynomial (see eq. (19)) to study functional relationship among the dominant curvature and two variable factors (h, dW). Polynomial coefficients were calculated using least-square method.

$$
\begin{aligned}
\kappa^{0} y= & 0.7819-62.561 \mathrm{X}_{1}+0.4158 \mathrm{X}_{2}+1158.4 \mathrm{X}_{1}^{2}- \\
& 0.00208 \mathrm{X}_{2}^{2}-7.8431 \mathrm{X}_{1} X_{2} .
\end{aligned}
$$

The obtained functional relationship (see eq. 19) shows that extreme of second order polynomial is minimum, but it is not in area of experiment (Fig. 7). To find out the adequacy of extreme value of curvature according to equation (19) was directly calculated values of curvature near extreme point. It shows that there is no extreme value. Maximal value of curvature is obtained when thickness of sheet is minimal (in range of experiment).

Adequacy of obtained functional relationship was verified by relative difference of actual value of curvature and value obtained by polynomial (see eq. (19)). Result shows that in all cases difference is less than $10 \%$. Therefore in engineering calculations functional relationship 
between total thickness of sheet and moisture increment/decrement and the dominant curvature might be approximated by second order polynomial.

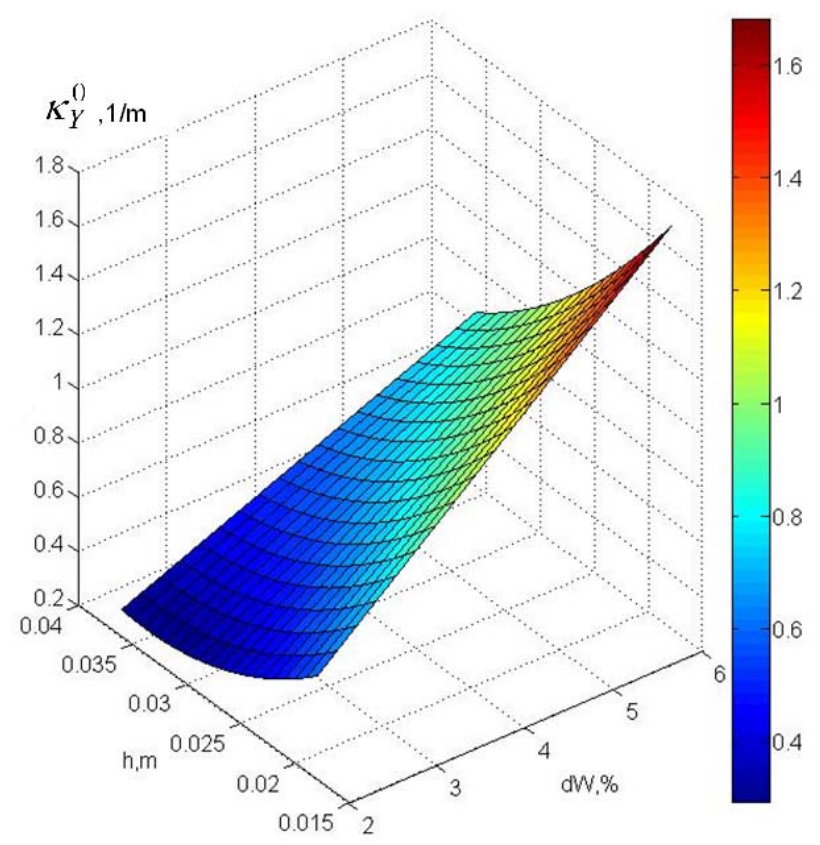

Fig. 7. The dominant curvature dependence of thickness of sheet $-\mathrm{h}\left(\mathrm{X}_{1}\right)$ and total moisture increment $-\mathrm{dW}\left(\mathrm{X}_{2}\right)$ according to eq. (19)

\section{Conclusions}

The inclusion of the curvature interaction effect and the variation of elastic properties of materials with moisture content improve currently used analytical method.

Curvature analysis of multilayer sheets by improved algorithm and finite element method shows that difference in results is not more than $10 \%$ in case if sheet is made from birch layers with orthogonal structure and typical geometric properties. Researched that taking into account curvature interaction effect the dominant curvature in some cases might be reduced by $50 \%$ and other curvature reduced by $80 \%$.

By making a numerical experiment with birch multilayer sheet of various geometrical properties and structure and moisture content of sheet has investigated the behavior of improved algorithm. Research shows that the greatest value of curvature is obtained when the ratio of thickness of longitudinal and shear layers are approximately five and all of share layers are placed together on top or bottom of longitudinal layers.

\section{References}

Brauns, J.; Rocens, K. 1994. Hygromechanics of composites with asymmetric structure, Mechanics of Composite Materials 30: 601-607. doi:10.1007/BF00821277
Brauns, J.; Rocens, K. 1997. Hygromechanical behaviour of wooden composites, Wood Science and Technology 31: 193-204. doi:10.1007/BF00705885

Brauns, J.; Rocens, K. 2004. Design of humidity sensitive wooden materials for multiobjective applications, Wood Science and Technology 38: 311-321. doi:10.1007/s00226-004-0242-8

Christensen, R. M. 1991. Mechanics of composite materials. Florida: Krieger Publishing Company. 329 p.

Decolon, C. 2002. Analysis of composite structure. London: Hermes Penton ltd. 336 p.

Grigorenko, A.; Yaremchenko, S. 2009. Investigation of static and dynamic behavior of anisotropic inhomogeneous shallow shells by spline approximation method, Journal of Civil Engineering and Management 15(1): 87-93. doi:10.3846/1392-3730.2009.15.87-93

Karkauskas, R. 2007. Optimisation of geometrically non-linear elastic-plastic structures in the state prior to plastic collapse, Journal of Civil Engineering and Management 13(3): 183-192.

Jones, R. M. 1975. Mechanics of composite materials. Washington D. C.: Scripta book company. 38 p.

Michnevič, E. 2006. A tool for modal analysis of laminated bending plates, Journal of Civil Engineering and Management 12(4): 319-325.

Reddy, J. N. 1997. Mechanics of laminated composite plates. Boca Raton: CRC Press. 782 p.

Reissner, E.; Stavsky, I. 1961. Bending and stretching of certain types of heterogeneous aleotropic elastic plates, Trans. ASME. Ser. E, 28(3): 402-408.

Rocens, K.; Steiners, K. 1976. Stiffness and ductability analysis for unbalanced monoclinic composite, Mechanic of Polymer (6): 1030-1035.

Rocens, K. A. 1983. Macrostructure theory of modification of wood properties, Journal of Appl. Polymer Science 37: 923-945.

Skudra, A. M.; Skudra, A. A. 2002. Ievads slāņaino materiālu mehānik $\bar{a}$ [Introduction in mechanic of composite material]. Riga: RTU. 116 p.

Vinson, J. R.; Sierakovski, R. L. 1986. The behaviour of structures composite of composite materials. Lancester: Martinus Nijohol Publishers. 323 p.

Whitney, J. M. 1987. Structural analysis of laminated anisotropic plates. Lancester: Technomic Publishing Company. $345 \mathrm{p}$.

Амбарцумян, С. А. 1961, Теория анизотропных оболочек [Ambarcumian, S. A. Theory of anisotropic shell]. Москва: Физматгиз. 384 с.

Белянкин, Ф. П. 1957. Деформативность и сопротивляемость древесины [Beliankin, F. P. Deformation and stiffness of wood]. Киев: Наукова думка. 96 с.

Перелыгин, Л. М.; Уголев, Б. Н. 1971. Древесиноведение [Perelygin, L. M.; Ugolev, B. N. Wood maintenance]. Москва: Лесная пром-сть. 281 с.

Уголев, Б. Н. 1971. Деформативность древесины и напряжения при сушке [Ugolev, B. N. Deformations and stress in shrinkage of wood]. Москва: Лесная пром-сть. $174 \mathrm{c}$. 


\section{STAČIAKAMPE்S ASIMETRINE்S DAUGIASLUOKSNE்S SANDAROS KOMPOZITŲ KREIVUMO SKAIČIAVIMAS}

\section{J. Šliseris, K. Rocēns}

\section{S a n tra k a}

Lenkiamujų konstrukcijų medžiagų sąnaudas mažina plokščio lakšto pakeitimas sulenktu arba balno pavidalo lakštu (kevalu). Šis pasirinkimas taikomas klijuotès lakštams užtikrinus, kad sulenkti arba balno pavidalo lakštai yra padaromi naudojant kelių lygių klijuotės presus su lygiagrečiomis lentynomis, imant tinkamų fizikinių savybių geometrinių matmenų ir orientavimo sluoksnius bei sukuriant struktūriškai asimetrinius lakštus, susijusius su viduriniu paviršiumi. Patobulintas dabar taikomas metodas kreivumui skaičiuoti, atsižvelgiant ị kreivumo sąveikos poveikị ir drègnio kitimo vyksmo tamprųjị būdingaji pokytị. Palyginti rezultatai, gauti patobulintu ir baigtinių elementų metodais. Taikant patobulintą metodą, apskaičiuotos kreivumo reikšmès lakštams, kurių yra ịvairūs geometriniai rodikliai ir įvairios drègnumo sąlygos.

Reikšminiai žodžiai: poslinkiai, kreivio sąveika, medienos kompozitas, drėgnio poveikis tampriosioms savybėms, balno pavidalo paviršiai.

Jānis ŠLISERIS is a scientific assistant in the department of structural engineering at the Riga Technical University, Latvia. His research interests include the modern constructions and non-linear technological mechanic of composite structures.

Kārlis ROCĒNS is a professor of structural engineering and director of the Institute of Structural Engineering and Reconstruction at the Riga Technical University, Latvia. He is a Full member of Latvian academy of sciences and participant from Latvia in COST activity C25 "Sustainability of construction: Integrated approach to life time structural engineering". His research interests include the modern structures, technological mechanics of wood and composite materials and structural material science. 